\title{
Great Storytellers of the World about the Soul Journey in the Universe
}

\author{
Olga A. Karlova* \\ Siberian Federal University \\ 79 Svobodny, Krasnoyarsk, 660041, Russia
}

Received 20.12.2016, received in revised form 22.02.2017, accepted 14.03.2017

The article is devoted to the up-to-date contents of fairy tale as a cultural gadget of the humankind. Clarifying the functions of a fairy story as a carrier for cultural memory and intuitive normative knowledge of the humankind, the author raises the problem of folk ideals in the historical and cultural retrospective reflected in fairy tales, including the age of post-industrial network information society, outlines the framework for the involvement of fairy tale in life design, formulates the hypothesis of the nature of fairy tale indifference to the borderline between life and death.

Keywords: myth, fairy tale, fairy tale archetype, fairy tale time-space, folk and literary fairy tale, fantasy, fairytalegraphy, fairy tale therapy.

DOI: 10.17516/1997-1370-0077.

Research area: philosophy.

Once some medical scientists happened to weigh the human body in a coma, and then, after a few minutes, following the person's clinical death. And it turned out that in the second case the body was lighter by 250 grams. Since then, the experiment was repeated many times: the loss average was varying slightly - from 200 to 400 grams, but it has always been observed.

Nothing is left to an accidental coincidence. Then what is it? Not measured by scientists an immediate "body relief", weight reduction with full relaxation of muscles? Or maybe the equivalent of the energy liberated in the decay of the body's physiological relationships?

Or is it the weight of the human soul, which leaves the mortal remains?
Body and Soul are two different human incarnations in their unity providing a man with an opportunity for productive life. To make them stay together after the death, long before our era great Egyptian doctors invented mummification, simultaneously the priests were learning to call out and reconnect the soul-doubles $\mathrm{Ka}$ and $\mathrm{Ba}$, and storytellers of the Nile Valley came up with a lot of plots concerning the soul journey in our wonderful and mysterious world.

Since then the millennia have passed. But the existence of the soul, ups and downs of its travel experiences have always remained the most important form of human existence in the Universe, i.e. necessary and in equal measure mysterious form. What our body does every day

(C) Siberian Federal University. All rights reserved

* Corresponding author E-mail address: O.A.Karlova@yandex.ru 
we can see in detail. But if one asks us about this elusive existence of the soul, only a few people could find the words to answer. Only while dreaming, meditating, foreboding, in trance, when the body is at rest or is subject to something unknown, our visions make us cognize this mystery, with which each of us is connected. At these moments, most of us are admiring and horrified, and of course, we cannot remember that it has been a while since culture created accessible to everyone the language to talk with the own soul.

Ones of the first to recognize this fact were the linguists. The Brothers Jacob and Wilhelm Grimm, the famous German philologists, throughout their life worked on the creation of German etymological dictionary. Considering the origin of words, they plunged into the history of folklore speech and, starting in 1808, they began to put down the tales from oral and written sources. The dictionary was never completed, but during their lifetime the Brothers Grimm became widely known, having created the genre of a book fairy tale skillfully "dressed" in folk costumes. This fairy tale is easy to distinguish by the presence of miracles, adventurous time and space, the simplicity of the narrator's and dialogic intonation, epic poetics and psychological motivations. Snow White and the Brave Little Tailor, Snow-White and Rose-Red, Frau Holle and the Golden Goose and many other bright characters of the Grimm Brothers' stories are jolly, bear the sense of folk authenticity and instructive meanings.

Like any language, the language of fairy tales is the alternation of words and silences, signs and "black holes", common values and individual semantic nuances. This language masquerades itself as a naive and simple one, but it is easily and universally conveyed by musical, visual and verbal means of different arts and generates real masterpieces.
At some point of his life Russian artist Mikhail Vrubel turned up to be completely captured by fairy tales. His paintings include not only the famous "Demon Seated", the incarnate symbol of human doubt, but also vibrant and extensive sceneries for Berendeis' country in "Snow Maiden" opera and the city of Sugar Candy in "The Tale of Tsar Saltan". Fairy-tale characters, such as a fairy in the lilac bushes and thirty-three bogatyrs in the sea foam, appear in Vrubel's works naturally and constantly because of the contemplation of natural forms, as if revealing the nature forces' essence. Mikhail Vrubel felt like an oracle of nature, trusting its secrets to people, and for many years he was like a prophet of pantheism, which in the late period of his disease desperately troubled him by sinfulness in Christian sense. Vrubel's "Swan Princess" seems to be slipping away into the darkness, turning only to muddle and to warn. His "Pan" is similar to a Russian peasant: he feels at ease among these fields and birches on the background of the mysterious night horizon. Before plunging into this folk night, the pan as if calls out to something essential in a Russian man and looks sternly and straight into the eyes of each spectator. Like his fabulous heroes, Vrubel quickly "descended into the darkness": he was only fifty years old when he was beaten by a serious illness, blindness, and death. And being already recognized by critics, he was followed by the words of another great Russian proclaimer of pantheism Alexander Blok: "I know one thing: in front of what Vrubel and those like him reveal to mankind once in a century, I can only be thrilled. Those worlds that they have seen we do not see, and it makes us say a poor, expressionless word 'genius"” (Blok, 1962: 690).

...This is so simple and so mysterious language of fairy tales. It was consistently practiced by those, who are best remembered for being great storytellers of the world. Many of 
them, as well as Wilhelm Grimm and Mikhail Vrubel, "celebrate" their anniversaries in 2016. Today, with their help, we will try to think through all three major incarnations of Fairy Tale - fairytalegraphy, fairylore and fairytale therapy.

\section{Fairytalegraphy}

The word "fairy Tale" has always hidden something exciting, childlike touching and wonderful... Scientists, who are considered to be serious and insightful people, often treat a fairy tale like children: they dissect it and by doing so they destroy and spoil it. In their books, the magic disappears and the fairy tale is presented only as "one of the genres of oral folk poetry; epic, mostly prosaic work of magic, adventurous or routine nature with the fictional setting" (Literaturnyy, 1987: 383).

But what of this, pronounced by science, makes a fairy tale understandable for us? In a nutshell, nothing. Perhaps more benefit is brought by a simple folk proverb: a fairy tale is a lie, but there is a hint in it, a good lesson to the good fellows. The French writer-storyteller Charles Perrault quite agreed with this statement, saying that morality is the main point in any fairy tale for the first place in the fairy tale belongs to the idea and evaluation of reality, and only the second place is taken by imagery.

So what are the important for us true lessons of fairy tales?

This is not so easy to understand, because when we turn to the fairy tale we find too many familiar and seemingly obvious things. For example, there is a common statement: "In the fairy tale everything is imaginary". If so, why did great Vladimir Propp insist on the following? "No plot of the fairy tale cannot be studied without the other, and, secondly, no motif of the fairy tale cannot be studied without considering its relation to the whole"? (Propp, 1986: 19) What is the reason for so many common plots in the folk tale regardless of the country and ethnic group? Finally, why are there regular and universal patterns, and why is the number of plots so small?

V.Ya. Propp in his book "The Historical Roots of the Wonder Tale" convincingly showed that a fairy tale has some reality. According to him, this is a historical reality of the past. He found it in the same themes and motifs. Where, for example, does hut on chicken legs in Russian fairy tales come from? It went the same way as a house built by Sun-son in the North American fairy tale. House's pillars are men, who hold the beam-snake and the beam-wolf, and they guard the building. All parts of the house are connected with animals and have their own names, as well as in Egyptian tales, which in surprising detail list all of the door parts in the magic house; the hero must name everything correctly, otherwise he faces certain death. Such is zoomorphic nature of the hut on the border of the world of the living and the dead, so Russian "chicken legs" also bear the ancient ideas about guarding animals. The conclusion is self-evident: the historical timespace of a fairy tale has hardly limited geography.

On the other hand, the search for the roots of the fairy tale in the historical past reality is, of course, interesting and necessary, but not sufficient. The texts also reflect another reality. Fairytalegraphy of the world is much broader and can be motivated by the present events, too.

For example, in the film based on the play by E. Schwartz "Cinderella" stepmother's relations prevent fairy godmother from punishing her, although the godmother highly appreciates justice: it is "very bad not to go to the ball, if you deserve it!"

Other "Cinderella", ballet by Sergei Prokofiev, is the clearest example of this fairy tale's conditioning by present situation and traditional ideas at the same time. In December 1940, Prokofiev in a letter to the theatre director 
set forward his conception of the ballet: "I consider "Cinderella" primarily as a Russian fairy tale, and mean to tell about the heroine in Russian musical language" (Perkhin, 2011: 166). This idea continued the composer's penchant for returning home theme, returning to "the atmosphere of the native land", to the original national culture "in all its original mental and ethnographic image of Russian folk forces", wrote Prokofiev. It was the idea of the mould of his affection for Eurasianism as opposed to Eurocentrism. This idea has completely coincided with the unprecedented rise of the Russian national self-identification in the 1940s. On May 24, 1944, in his radio speech Prokofiev specifically pointed to "Masha Chernushka1", the Russian version of Cinderella in the Afanasiev's collection of Russian folk tales. The composer emphasizes the connection of his ballet with the heritage of Russian folklore collector Afanasiev, with the Russian $18^{\text {th }}$ century culture, and therefore, with the historical motifs of the Elizabethan era, rather than with literary and musical scenes by Perrault or Rossini. Although from the 1940s to the present-day critics have attributed the Prokofiev's plot to the Perrault's tale, it has little to do with the composer's position. More likely such statements prove the fact that critics simply do not know other sources. But Prokofiev's expressed ethnic flair leaves no doubt that the composer created in his ballet bright national and fairy images and meanings.

I cannot but disagree with the other clearly false axiom: a fairy tale is a relic of the past. Probably no one will argue that the epic George Lucas's "Star Wars" is not only a tribute to the past, but also the concept of the future. Evidently, fairy tales which use this type of fairytalegraphy are special. In the West, a special genre of "fantasy" was invented to distinguish them from the historical folklore and even literary fairy tales. This delimitation was mentioned by the famous Polish science fiction writer Stanislaw
Lem, who also celebrated his anniversary this year. "Imagine a story in which some orphan was kicked out of the house by a wicked stepmother. In the forest the orphan finds a chest of gold coins, but the coins turn out to be fake, and the orphan is sent to prison for counterfeiting money. So, the fairy tale violates the genre conditions and goes beyond its usual ontology. But prison walls fall apart and there is a fairy who takes the orphan out of prison. However, before the fairy utters a spell, which should transfer her and the orphan to the right place, they both fall under the passing coach, breaking their arms and legs. If fairy knows a spell that allows them to remedy their broken limbs immediately, this is after all a fairy tale, but if they both get to the hospital first, and then to the gallows, this is not the world of classical fairy tales, but something else. What is it exactly? What is this world where there may be such a fairy, good-hearted and at the same time powerless against evil? This is the world of the fairy tale latest version, namely fantasy" (Lem, 1970).

In fact, Lem says: fantasy is non-canonical fairy tale. But how big is the difference?

It is well known that Tolkien's fairytalegraphy has very much in common with the Old English "Beowulf", in which he was recognized as an expert. There are some allusions to "Beowulf" in decisive battles in the dragon's lair and the cup's theft in "The Hobbit", as well as in the military feasts, orcs' and nazguls' descriptions in "The Lord of the Rings". And even the protagonist's name Frodo migrated from this epic. However, Tolkien borrowed no less motifs, characters and storylines from the Old Norse "Edda", Finnish "Kalevala", Icelandic sagas, the German "Song of the Nibelungs". The immortal region, where Bilbo and Frodo set off in their last journey is an allusion to the epic of the Aman mainland and the Eressëa island behind endless ocean. Such was the sacred geography of ancient Europeans, 
from Greeks to Scandinavians, to imagine this area in the ocean on the western edge of the world so that the sunset indicates the way there. There they fall after death, and before it, necessarily in a boat, like the dead Tolkien hero Boromir or the medieval king Arthur, who received a mortal wound and went to the Avalon island. Thus, this Europeans' belief in magical islands did not disappear even under Christianity. By Tolkien, Avallone means "not far from the house of the Valars": both in the epic and in the "Silmarillion" this place is not heaven, but a magical land where wounds are healed, and the life of people, fairies and elves slows down, promising peace and prosperity until death. Such is the historical inversion that arose from the author's desire to place his books into the world's fairytalegraphy (Colbert, 2003: 21-22).

Possibly we can agree with the Russian explorer of fantasy Ya.V. Korol'kova that the root of all subsequent fairy tales is a folk tale, as there a norm is the miracle, while the characters have distinct character traits (Korol'kova, 2010: 142-144). And the very fantasy, emerged as the antithesis of rational science fiction, does not stand still: in contrast to the classical genre there has appeared "black fantasy" and other nonclassical kinds. So, the obvious question is what the canon is, and to what extent it is strict or, on the contrary, historically open?

Or maybe the whole problem might be reduced to the analysis of the way that the humanity went through the last century. Where does our civilization vector lead us? In this way, a modern man finds it more and more difficult to believe in the absolute victory of good, and existing in the restless soul hope for miracles of harmony and justice increasingly fades away under the pressure of an aggressive chaotic reality.

Again and again world news and world cinema convince us in this. Info-fairytales of the world media are confidently striding across the planet, and the dominance of Hollywood seems total. Yet, in the world globalism, thank God, there are serious gaps. F. Dostoevsky in his article "Two Camps of Theorists" wrote about the national tasks of different nations. They have existed from the start and they explain both ethnic cultures' features and the structure of the various national languages. Of course, there is no antagonism in such problems, but the specifics is plain to see.

From this we can make an interesting observation: fantasy, defined in the European tradition as a genre, translated into Russian simply as "fantazia", implying a fundamental feature of human thought. At the same time, it must be noted that although it is a universal property, it is still more consistent with the creative thinking, which is actually a brand of Russia, the Russian nation and its people's soul.

Amazing physicality of fairy tale metaphors was brought into life in the Soviet cinematic tales thanks to the film director Alexander A. Rou who along with creating a new genre made sixteen fairy tale films. Participating in ideological battles in 1938 to create his first film-tale "Wish upon a Pike," he made an important discovery, entrusting live artists making wonders on their own. Rou believed that film is the most suitable means to turn everything into a miracle in its physical realization. And when in a fairy tale about Emelya after the magical words: "Turn, fierce winter, into red summer" the audience saw fragrant and hot summer set, they were unaware of the fact that by this time film shooting had been disastrously protracted, so the "miracle" helped the team to save their budget. Rou created a "magical star bouquet" of fairy tale artists who brilliantly embodied his most daring ideas in the amazing acting realization on the screen. Several Soviet generations could not conceive a fairy tale film without George Millyar. Stating 
the value of people's understanding, the Soviet fairy tale shot by Rou cultivated such qualities as friendship, loyalty, patriotism, and taught to appreciate the sacred value of nature. Having travelled around almost half the world, the son of an Irish engineer and Russified Greek mother, Rou said that the symbol of his work are slender birch trees, as if descended from paintings by Nesterov. These landscapes, grass and trees in his fairy tales are more important and beautiful than magic chambers and palaces. Ready to creatively convert any plot-line, Rou was surprisingly scrupulous in artistic and physical realization of national natural images of a Russian fairy tale. Dawn in his films is always red, the sun is always bright, birches are slender and elegant, the forest is dense. In short, there is no less pantheism in Rou's motion pictures than in those of Vrubel or Blok. For Rou, it was the Russian nature being the temple of fairy tales, where they were told and listened to in a special manner. "Narrators make up and tell fairy tales in twilight, when all living things and objects, illuminated by a mysterious light of the setting sun, change their shape. In such a situation, sitting somewhere on the hill, I was listening to fairy tales in the distant days of my childhood" (Rou, 1973: 5).

Twilight on the verge of day and night, light and shadow, the half-conscious, half-dreamy state is the sacred moment of reality, when the soul is revealed towards the image of the Universe. And we believe it appropriate to formulate the hypothesis that it is a fairy tale, with its amazing geography and its archetype, which tells the eternal story of the soul's journey in the Universe. This travel is no less real than the physical body movement.

In one of the climactic scenes of the movie "Harry Potter and the Deathly Hallows", being under the killing blow of Voldemort's wand, the hero falls into a kind of light-filled and calm space, where he meets Professor Dumbledore.
Having received far from all explanations of what was tormenting him, Harry tries to stop the departing professor with a desperate question: "Professor, is this really happening on, or is it just in my head?" He hears a remark which is amazingly logical: "Of course, this happens in your head, but why should it not be real?"

If we feel and understand what a fairy tale is doing with our soul, it means that one more seemingly obvious postulate fails. This postulate states that the fairy tale is intended mainly for children.

\section{Fairylore}

For that there is one more reason: the further the mankind goes on a civilization way, more and more people address to myths and fairy tales. And so, the greater is the number of fairy tales for adults. Have you noticed that a fairy tale likes to make riddles? In a variety of fairy tale scenes, we find this check for cleverness, however (and this is important), the price of the right guess is life or death. Perhaps, this point is not very exaggerated, especially when one takes into account that the fairy tale does not only reflect the history, but also carries the code of the future. Many philosophers in the $20^{\text {th }}$ century wondered: why did humanity lose the ability to foresee the future? This ability was inherent in the Maya and Aztecs, the ancient Greek oracles and Chinese diviners, the Scandinavian druids and the ancient Russian saints. Supposedly, the tribes and peoples in the civilizational false pride rejected secret knowledge, and pushed its historical cipher (a fairy tale) into the culture periphery as an object of entertainment for silly little children?

In the textbooks, it is written that folk tales are classified into magical (wonderful) and everyday (common). But here is misnaming: even in so-called everyday fairy tales there is very little everyday life and it is presented very indirectly. What is in the fairy tale then? What 
is this whole fairylore that does not even explain anything? But the matter is that we are dealing not with an explanation, but with the justification of the world, the definition of its ideal structure and the human place in it. This feature of fairy tales is developed in the sacred myths and sacramental texts of many peoples, in particular, in hagiography. Masons also quite consciously used this feature for their own purposes.

Freemasonry in the $18^{\text {th }}$ century, century of the Enlightenment, was drawn primarily to the ideas of the cosmogonic myth. However, while the ancient myth was syncretic and indivisible, Freemasonry as a life religion put forward daily existence of people as its sacral core. It proves the possibility of integral and highly spiritual human being, who bases on ethical postulates. In this logic, Wolfgang Mozart, referring to the Egyptian myths, recreates in his "Magic Flute" cosmogonic structure: by the musical means he renders a utopian ideal of fair world order, the Golden Age of humanity and human place in it. How does he tell this? The libretto was originally based on the confrontation between a good fairy and an evil wizard; this struggle involves the lovers Tamino and Pamina. This libretto was modified and possibly changed by Mozart himself, as suggested by researcher Eric Neumann: the fairy godmother became the Queen of the Night, representing evil, and the evil sorcerer turned into a priest of light. In accordance with the change of values, the secret symbolism of Freemasonry was not only included in the libretto, but actually became its fundamental content, directing the internal development of the plot. The magic fairy tale opera laid the foundations for multilayered mystical drama, revealing the composer's Masonic religiousity and his ethical views. Differing from the fairy tale narrative contradictory layers of the libretto text are alike dreams, which are characterized by the discrepancy of the conscious and the unconscious. However, the content of these "illogical pieces" is no less important for the opera than the logical and coherent content. This explicit combination of incongruous things hides Mozart's "Masonic Symbolism", which is allegorical and consciously rational rather than delicately sensitive or syncretic. Such, in contrast to the ancient sources of the fairy tale, was the moralization of the Enlightenment. In Mozart's musical language, this manifests itself primarily through the use of a sacral key (E flat major) and related $\mathrm{C}$ minor and $\mathrm{C}$ major (Kuznetsova, 2014). In the opera plot, there are a lot of typical fairy tale motifs, i.e. snake-fighting, the hero's test of silence, passage through fire and water. The ambiguity of the characters repeats the fairy tale morphologic structure, however it is more systematic in a Masonic way, so each hero has his/her double-trickster.

Tamino, the cultural hero of the opera, goes "through the night to light", transforming and reviving. "A man of culture" was understood by the Freemasonry adepts as a compound of moral and aesthetic origins in a purely patriarchal spirit as opposed to women's destructive origin. Yet still, everything is not so simple in the narrative: the magic wonderful flute is a gift of the Queen of the Night, who genuinely suffers from unbearable loss of her daughter. On the other hand, the beneficent magician Zarastrosam commits violence, and the fate of the abducted by him Pamina is governed by the wicked Moor Monostatos. The genius of Mozart, who perceived life in all its complexity, was higher than any Masonic constructions. With the Pamina's voluntary separation from the mother this character becomes a symbol of free and harmonious, loving and beloved personality, who alleges a new world order. Thus, the narrative ambiguity in the "Magic Flute" is multilayered, it manifests itself in musical harmony and melody, constant combination of choir and songs, which is the hallmark of primarily Masonic Mozart's writings and operas. 
In his last decade, Mozart created about 30 works in the "Masonic" key (E flat major). Most reminiscent of "The Magic Flute" are his works for winds, given the symbolic importance of winds in the Masonic rituals. Romanticism as the pinnacle of the great discoveries of Freemasonry for the first time ever theoretically comprehended the objective impact of ancient fairy tales and music on people. Romanticists mythologized not only Mozart's work, but his name, too, creating an imaginary ideal figure of the composer.

Mozart's opera "The Magic Flute" was one of the plot sources for the fairy tales by Theodor Amadeus Hoffmann. Gottlieb Heinrich Schubert identified their spiritual origins in natural philosophy, it was the realization that the original harmony of the world gave way to discord. Only in prophetic dreams, in a creative search, and in the faith a person can see the future and find a harmonious unity with the Divine origin. E.T.A. Hoffman's hero in "The Poet and the Composer" broods over the fact that music is the mysterious language of the distant kingdom of the spirits; it is addressed to the soul and awakens high and hard life in it.

In the genre system of romanticism, the literary tale occupies one of the central places. It is generally believed to be created either by free interpretation of the permanent plot lines of a folklore fairy tale, or on the basis of an original plot in which magical and fantastic elements are widely introduced. Romanticists were attracted by the form of a fairy tale, which most accurately and deeply conveyed the "folk spirit". Going to the fairy tale world is a kind of escape from the real world, so the fairy tale and reality turned out to be a manifestation of the romantic "twoworlds" scheme. This scheme was lavishly used by Hoffmann: in his works caustic satire is interwoven with subtle lyricism and tenderness. For the most part Hoffman invented his own fairy tales or rethought traditional ones. The idea of creating the first tale "The Golden Pot" (1814) came to Hoffmann, when he was going to Dresden in search of work and there was experiencing the hardships of war. On August 19, 1813, in a letter to his publisher Kunz he writes: "In this dark, truly fateful time when I could only do with that I could still eke out my days, I was completely captured by the writing as if in myself I discovered a wonderful kingdom, which, coming from the depths of my being, was embodied in images and carried me from the onslaught of the outside world" (Botnikova, 2005). Such is the power of a fairy tale, which Hoffman used to measure the real life of his time and realized that this reality does not afford ground for fairy tales. Therefore, Hoffman's real world is inhabited by hideous monsters in human form, and mythological harmonious ante-world enters the Hoffmann's fairy tale as a remembrance, a dream about the beginning of all sources.

The word "fairy tale" in Hoffman's poetics originally had a metaphorical sense. It embodies the magical land of happiness, realized desires and the beauty of the spiritual human origin. He calls the human soul in the "Princess Brambilla" the most wonderful fairy tale in the world. Hoffmann had the chance to predict a lot of true for his time things and, above all, the terrible and impersonal power of money. Philosophical Hoffmann's fairy tales are aimed at adults, perhaps, only two of them are related to the world of childhood: these are "The Alien Child" and "The Nutcracker and the Mouse King". "The Nutcracker" is a kind of "inverted" folk tale: when the folk tale takes a child into the realities of the adult world, "The Nutcracker", on the contrary, remakes the world by the beautiful children laws of goodness and beauty. This world is available to quaint people, "enthusiasts" of all ages, as romanticists assumed. So quaint was Mr. Drosselmeer, he created whole toy towns that gather dust under the glass, being only an imitation of real life, because a fairy 
tale cannot be "made" or "bought", it is created only by loving hearts that can see the true beauty despite the outer ugliness. Wonderful world of childhood is not always associated with age: in fact, Marie's brother being the same age laughs at his sister's worries as quite a grown-up, he has different actions and dreams. Actually, in Marie's life a fairy tale begins only when she falls asleep beside the closet with toys. The fairy tale is nothing but images of a dream, a fantasy or traces of impressions, which are separated from reality. Moreover, in the final Marie finds quite real explanations of her vision: perhaps these were associations, inspired by the flashing flame or a keychain with seven rings. Does it mean that a secret of wonder gets a key and, hence, a fairy tale quits the life? Not at all. Too bright and multifaceted is Hoffman's magic lantern. Unforgettable are the battle between the dolls and the mice under the Christmas tree, the peaceful picture in the palace kitchen, where the royal couple cooks dinner, the Candy Kingdom with the Orange Brook, the River Lemonade and Comfit Grove. Marie was rewarded for persistence and devotion: the ideal is conceived as inherent in the human nature origins of kindness and courage. Like Mary, the poet Balthasar in the fairy tale "Little Cahes" also begins to see the truth, sees people as they really are. Political tyrants, like Little Cahes nicknamed Zinnober, are erected by a crowd of middlebrows who do not need magicians and creators.

It is interesting that the author has defined a genre of his fairy tales as "capriccio", meaning the creator's caprice or whim, where there are many unexpected plot twists, momentary change of moods and bizarre fantasies, funny jokes and fascinating tricks. Today, in the postmodern era, his grotesque and ironic fantasy are very timely. Three hairs, donated by the merciful fairy to a little monster and making him omnipotent, for long stayed an allegory of romantic anti-fairy tale.
But wealth is not the only fetish of civilization. The desire for power, for world domination, for being on a par with God is the actual motif of many contemporary stories in different genres. D. Andreev in "The Rose of the World" says that Lucifer always creates his own universe in his conception. Such is the moral foundation of the devil as a religious image and the demonic personification in a man. In fantasy researchers rightly see anti-science fiction, as fantasy is a genre, opposite in its origins and meaning to rational science fiction, which was the most popular at the time of the optimistic belief in the absolute power of man.

In their article "'The Lord of the Rings' as a Myth of Post-Industrial, Network and Information Society" (Gruzdeva, Kolmykova, 2011) E.N. Gruzdeva and V.V. Kolmykova claim that the author's myth, just like any other, cannot be classified as "fiction" for it can set its standards: it is just as real as language, religion, science, or politics. Here is another argument: "the spirit and letter" of the trilogy conform to the information and network society standards which came to replace the industrial formation, accumulating all the fears of its age. In his essay "On FairyStories" Tolkien himself wrote: "The maddest castle that ever came out of a giant's bag in a wild Gaelic story is not only much less ugly than a robot-factory, it is also (to use a very modern phrase) "in a very real sense" a great deal more real. Why should we not escape from or condemn the "grim Assyrian" absurdity of top-hats, or the Morlockian horror of factories?" (Tolkien, 2010: 392). Lewis Carroll, on his part, was amazed at how accurately real events followed the stretch of the authors' imagination.

So, besides the eternal archetypes, the fairy stories of all ages have to fight their own dragons. Here is an ancient fairy tale: the hero is the one who gets swallowed, for it reflects the essence of an initiation ritual. Some time passed; in more 
modern stories the hero is the one who kills the swallower. This illustrates the loss of connection with the ancient principium of the world, and how modern "common sense", the equally natural and tragical phenomenon for us, begins to dominate. For, as we can see from history, progress means more than just informational and technological breakthrough; it is the balance within nature the man is a part of. The essential perception of itself as an organic part of both natural world and the wholeness of Existence the humankind needs to perish and preserve, is gradually disappearing. The humankind treats its ancient culture like a baby tossing its cubes around, unable to foresee the consequences of its deeds. Having got convinced in its eternal power, the Western world rejected the arcane knowledge of nature, related to the natural subconscious centres within the man himself. It made all civilized knowledge explicit and scientific, though powerless in many ways.

In her monograph "Mythology of Good and Evil", E. Ivanova rightfully remarks that it was quite reckless of modern science to reject the intuitive and fairy-tale knowledge in favour of rational scientific concepts. "It was the mythological method of world perception that formed the algorithm for the dialectic method for analysing the surrounding reality, nature and society. The algorithm was, perhaps, developed by Laozi and Heraclitus, gradually mastered by multiple outstanding thinkers throughout human history, and transformed into a universal method of cognition. As it has been proven by researchers, one of the functions of the myth is consolidation of vital information in the memory of humankind. Some important myths preconditioned a series of fundamental methods of cognition" (Ivanova, 1999: 3). A. Losev suggested that it is the mythological thinking which still exists in a fairy tale that strives to overcome the clash of the opposites with a special mediator.
The ultimate opposites thinkable by the humankind are life and death. Scary and mysterious, and therefore attractive motifs of death are repeated in fairy tales of multiple nations, which makes them impossible to ignore. V.Ya. Propp draws our attention to the fairy-tale motif of a rope bridge associated with the death of an old king who wishes to marry the beauty brought to him by the hero, but who, unlike the hero, cannot walk on the rope or the perch across the pit and falls into it. The author writes: "An enormous number of researches demonstrate that this motif is caused by the perception of the kingdom of the dead as divided from the world of the living with a thin, hair-like bridge the dead or the souls of the dead walk across" (Propp, 1986: 339). For the Incan people, it is a hair bridge; according to the fairy tales of North American peoples such bridge lies on the heads of the buffalos who bow as someone steps on it. A razor-thin bridge to the country of the dead is also found in the Eskimo fairy tales. L.Ya. Sternberg wrote of a similar one in the stories by the Ancient Persians: it is called the Chinvat bridge. "A holy soul may joyfully march along, following a beautiful girl embodying its good deeds, and accompanied with good dogs guarding the bridge. Then the soul goes to heaven, and, finally, makes its way to the golden throne of Ahura Mazda... While evil souls find no helpers. They stumble on the hair-thin bridge and dash into the abyss. An evil demon catches them and takes them to the darkness" (Propp, 1986: 339). According to Propp, a fairy tale extrapolates this motif to life, turning the consequence into the cause of death.

However, the researcher does not ask why the fairy tale does so. Why does not it distinguish between life and death? Since it is very important, let us clarify: is the main task of the fairy tale just to distract people from their fears of the unknown future? Or does it have something to say of the existence of life after death, is it more 
than just a means of psychological support? Perhaps, it is more relevant that, being a language of communication with the eternal soul, the fairy tale does not care of the borderline between life and death, i.e. the indifference of the fairy tale to the borderline is the indifference of the soul itself as an eternal traveller around the Universe?

It is extremely interesting what the texts of folk wonder tales speak of human soul. As a rule, in wonder tales, souls get kidnapped by the dead who appear in the likeness of various animals. That is how the quite sophisticated soul objectivization process manifests itself. Just like Ancient Egyptian tales, the tales of the Dakota people state the existence of four souls. There is a soul of the body which dies together with it; there is a spirit which remains with the body, there is a soul responsible of the deeds of the body which goes west or south. The fourth soul lives in the tuft of the dead man's hair until there appears an opportunity to throw it to the land of the enemy, where the soul will wander, bringing diseases and death to the enemies. The Bantu people also believe in four human souls, one of which, the external one, exists in the likeness of an animal connected to the body, which can be a leopard, a turtle or a fish (Propp, 1986: 248).

In many myths, soul is presented as an independent creature able to live separately from the man. One can have a soul which lives outside, like Koschei the Deathless, who hid it on the tip of the needle inside a zoomorphic "matryoshka" of a hare, a duck and an egg, or, like Voldemort, scattered it between multiple horcruxes including Harry Potter himself.

Soul is associated with the pursuit and transfiguration motifs of the fairy tale. In Russian fairy tale of the seven Simeons, the tzarevna turns into a white swan and flew away from the ship. In many Slavic fairy tales tzarevnas, or princesses, turn into birds, for example, into a duck, and later, when the tsarevich wishes to return his beloved her human appearance, into a series of other animals, as though resisting the return. Researchers find similar motifs in the tales of the African tribes of Yoruba and Popo, or in Egypt, where the dead could transform into a heron, a snake, a crocodile; in other words, the soul would transmigrate into these creatures. Such motifs underlie the Indian doctrine of metempsychosis; they are found in European antiquity. For instance, in the Tibetan tale of cunning science, we read: the soul of the king jumped out of a fish into a pigeon flying by. The shamans of the Siberian Buryats go hunting the souls of the dead just like a chaser in the likeness of a bird of prey, attacking a soul transformed into a swan.

But if the soul is an eternal energetical wanderer transmigrating into the phantoms of the material world, let us ask: why isn't it capable of "recalling" its astral and mundane "biography"? But if the diagnosis is this, the culture obtains another special instrumental function.

The word "culture" originated from the ancient "coult", or fostering. As interpreted by philosopher D. Pivovarov, it stands for fostering ideals or standards, while standards are closer for the west, and ideals are closer for Russia. It means continuous, cyclic fostering, as cultivation of a field, tilling it for each new generation. It is directly related with a wonder tale where miracles and magic appear as something perfect, or idea. The ideal is real for us, though we realize its principal inaccessibility. Let us claim that a fairy tale is both the analogue and a tool of cultural memory, for it is its "surprise not overburdened with material short-term concerns" (Loyko, 2002: 30) the fairy tale and culture itself began with.

As collective memory, culture first of all manifests itself in the fairy tale through the constants of texts, the unity of cultural code, through the continuity and consistency of transformation. It also reveals the rhythm of 
culture, the rhythm of cultural "forgetting" and "recall". G. Deleuze rightfully suggested that everything in the world is "past-coming", as the past has not passed and it is "contemporaneous' with the present that it has been" (Deleuze, 2000: 139).

One may, indeed, create a fairy tale based on a certain pattern or without any and, just like Tolkien did, say: "My world was born together with me". But still, even in his story, the dying kind Théoden, addressing the "glory of the ancestors", keeps repeating: "I go to my fathers, in whose mighty company I shall now not be ashamed", as though it was a prayer. Yes, the descendants described in Ancient Russian texts are not the only ones to realize that they would be remembered only through repeating the "glory of their forefathers". Just like Harry Potter "the wonder boy", desperate for the support of his dead parents he believes to be the personification of all his ideals, young Skywalker from the trilogy by George Lucas seeks encouragement from the deceased Jedis.

If we agree with M.M. Bakhtin that culture is standing on the verge (Bakhtin, 1975: 25), it is correct to say that this verge coincides with the horizon of the fairy tale.

As we have found above, without special taboos and cultural rituals, new codes change the meaning of the fairy tale texts for us. To my mind, fairy tale studies are able to answer the question how far the pendulum of meanings of a modern fairy tale may sway. In its turn, fairy tale therapy may answer, why a fairy tale may need change of its canons.

\section{Fairy tale therapy}

Plunging into today's cultural annals seeking for fairy tale representatives, it is impossible to ignore another story teller and this year's anniversary hero Walt Disney, the independent owner of former Buena Vista Studio and the Disneyland, the owner of a fortune worth
80 million dollars, a television magnate, doctor of fine arts awarded with the Presidential Medal of Freedom, the greatest civilian award of the United States, along with thirty academic awards. The career of the artist which ended with a truly grand finale, had a pretty humble start. The work on the first full-length cel animation feature film "Snow White and the Seven Dwarfs" was a great financial risk. But still, Disney won this round: he became the crowned king of cartoon animation and a millionaire. Replying the criticists' doubts concerning the genre of the masterpiece, Disney "sarcastically smiled and said, 'I spent almost two million dollars on this film. Isn't it a fairy tale for you?!" (Arnoldi, 1968: 99).

So, was Disney really a "knight of fairy tales"? Disney recalled the moment when he brought his father to the new studio for the first time. His father, a construction engineer, studied the building for a while, and then asked: "Walter, what can it be used for?" His son answered: "It's a studio, a studio where I work". And the father said, "No, Walter, what can it be used for?" With a deep sigh, Disney shrugged his shoulders. "Oh, I see, Dad. This would make a perfect hospital" (Arnoldi, 1968: 111).

When he had the idea to create Disneyland, many people considered it to be a silly fantasy costing 100 thousand dollars. But within several years the fantasy proved to be a large and profitable business. French critic Maurice Bessy called Disney "a poet under the mask of a businessman", claiming he could combine an unrestrained poetic fiction with the famous American business drive, the elevating joy of free, breath-taking fantastic dreams and the robust sense of solid ground under his feet, comprehension of the wonder tale spirit and the knowledge of reality and business climate, the right resourcefulness (Asenin, 1995: 209).

Creative practice theory describes a method called "the Disney strategy", which divides the 
roles of the Dreamer, Realist and Critic. There even were three separate rooms for them in the studio: in the Dreamer's room, there was bright and colourful chaos, the Realist's space was a modern animation table, while the Critic resided in a small closet under the staircase. It was a fantastic key to the management of group creative process. In February 1957, President Eisenhower wrote Disney a letter, where he remarked the most relevant feature of his work: the ability to teach the young generation the optimistic concept of human life. So, in the mid- $20^{\text {th }}$ century in America the world's first fairy tale therapist made his first successful experiment.

However, the term of fairy tale therapy did not exist back then. Experts on human souls discovered the fairy tales full of images and symbols, organic to our subconscious, only 20 years ago. But today psychology insists that at any age fairy tale therapy can be used to develop emotional intellect, self-consciousness, self-regulation, social sensitivity and ability to manage interpersonal relations. It also requires to determine the unique pattern of the person's destiny. The efficient and developing fairy tale therapy is based on four principles: cognition and accumulation of the Vital Force, creation of a Bridge between the inner and outer realities, development of self-discipline for imagination, feelings and deeds. And, finally, the fourth principle is comprehension of a wider range of life situations, overcoming the "narrow consciousness", or, in other words, the Crystal principle. A wonder tale always has all these "healing powers".

Nevertheless, the therapeutic capabilities of a fairy tale are efficient only provided that: 1) the fairy tale archetypes are correctly selected for the certain person's "destiny pattern"; 2) the image range is comprehensible to the addressee; 3) the appropriate narration style is developed in a dialogue with the addressee. In her "Practicum",
Tatyana Dmitrievna Zinkevich-Evstigneeva gives some interesting examples of such styles on the basis of the well-known fairy tale "Ryaba the Hen".

"Once upon a time, there lived an old man and an old woman. They lived in harmony, never complained, looked up to each other. Their beloved pet, Ryaba the Hen, who laid delicious eggs, was a great joy of their lives. But one day the hen laid an egg, not an ordinary one, but a golden one". It turns out that this well-known traditional introduction can be "interpreted" in various styles: "Many men and women are equally miserable, but everyone is happy in their own way. Let's say, there was He and there was She. No matter how many things happened in their life, there was an invisible force that kept them together. No one could tell what it took happiness to reach their humble hut. But once a Golden Egg, for an unknown reason laid by their speckled hen, appeared in their house". An "extremely modern" "Ryaba" would look as follows: "Listen guys, there lived a dude with his chick in a kinda funny house, they lived ok, not giving a damn about anything, eating nothing but eggs. But maybe some shit happened to the eggs or the dudes just got high, but they started seeing things. Like a Golden Egg their hen laid". And, finally, here comes the sci-fi "Ryaba": "By the year 3047 breeding new animal species had become fashionable among terrestrials. One scientist with a spouse decided to create a special breed of hens that would lay golden eggs. The couple immediately fed all the golden jewellery they had to the experimental group of the laying hens. They managed to develop a breed of hens with golden feathers, gold plated beaks and even one specimen with a golden telescopic eye, but no one of them laid golden eggs. But one morning the whole 26-th level bedroom suburb woke up of a horrifying scream. "Another side-effect of the experiment", the neighbours thought, and turned 
the additional sound isolation on. But that was the long-awaited result: the hen No. 20987647362542 with speckled feathers pushed a real golden egg" (Zinkevich-Evstigneeva, 2016: 12-14). Thus, the style of "Ryaba" can be limited with nothing but the imagination of the narrator. It proves that the essence of a fairy tale is its archetypical concept and the individual meaning each addressee finds in it.

So, the ideology of the Soviet Union, built on a powerful base of socio-centred religion called "Atheism" intensively used the fairy tale motif of future retribution for the labour and courage of Soviet women. Starting from the 1930s, lyrical comedies have been using the image of a Cinderella who made her dream come true due to the "miracles" of the Soviets: the characters of Ladynina of "They Met in Moscow" and "The Tractorists" by Ivan Pyryev become the nation's favourites; in the finale of "Tanya" the servant Tanya Morozova becomes a weaver known all over the country, and another servant, Anyuta from "Jolly Fellows", becomes a singer. However, a motif is not yet an archetype: the dramatism of the Soviet age remains out of vision, hidden behind the lyrical carnival of love, friendship, labour and dreams coming true.

However, literally in the same years in Russia appears a "fairy tale antidote" to the sociorealistic "prided and joy". Despite the nod toward real friendship, love and humanity, the fairy tale opposes useless demagogy, oppression of personality, grovelling psychology and pressure of totalitarianism. It is first of all associated with the name of an outstanding writer Eugeny Lvovich Schwartz, deeply devoted to fairy tale and the truth of life at the same time. Since 1925, he had written around 60 books, and several generations grew up on his play-movies "Little Red Riding Hood", "Cinderella", "The Naked King", "Two Maples", "Tale of Lost Time", "The Shadow", "The Dragon", "The Ordinary Miracle" as on real revelations. Explaining the idea of "The Ordinary Miracle", Schwartz wrote in the introduction: "Among the characters of our fairy tale you will recognize some people you come across quite often. Like, the King. You can easily recognize him in an ordinary home despot, a feeble tyrant explaining his debacles with principles. Or cardiac muscle dystrophy. Or phrenasthenia. Or just genes. We made him a king in the tale for his traits of character to reach their natural extreme" (Schwartz, 1992: 5). The "natural extreme" of wonders in Schwartz's fairy tales never interferes with the realization of the ordinary, of the things important to us in everyday life. Maybe, it was because his motto was a very deep thought: "To create, you must know first".

The fairy tales by Schwartz seem to be "distant relatives" of folk wonder tales. He did not even process their motifs and plots, creating original versions of certain fairy tales by Anderson, Charles Perrault, Chamisso, Hoffman. But what is surprising: the archetypes of these modern fairy tales are built with complete compliance to the matrices found in folklore by V.Ya. Propp: interdiction, violation, trickery, villainy, lack, mediation, unrecognized arrival, recognition, transfiguration, wedding. The modern fairy tale genre returns to the archetype of folk tale at a new dialectic level, which is the factor that makes Schwartz's dramaturgy so bright and convincing, contributing much humour, satire, psychological elements and carnival culture. The play kaleidoscope is full of unrestrained fantasy: in "Cinderella" the King complains of Puss in Boots who does not wish to have fun at the ball, and the Hop-O'-My-Thumb, who, on the opposite, keeps playing hide-andseek for money. All fairy tale characters co-exist side by side in Schwartz's fairy tales; they look up to the future, which makes them miraculously unpredictable within the frameworks of their types. 
So, what is the main archetype of fairy tale as such, in any style and genre? To answer this question, let us try find something that is absent in the fairy tale.

To our surprise, we shall find that despite its moral geography and the ideal model of the world, despite its psychotherapeutic capacity the fairy tale never addresses God with a prayer. Maybe, the ancient fairy tale is older than prayer as such? However, neither new literary fairy tales nor fantasy never speak to God either.

Why is it so? Maybe, because fairy tale is a religious text itself, but in a magical and ethical, not theological capacity. By the way, in the historical retrospective this aspect is never denied: it is accepted that there was time when myth disappeared from cultural life as an ancient religious ritual and an actual product of consciousness, while its remains were used for entertainment and education of children. However, it is still stated that fairy tale is not only and not as historically as universally religious. In other words, both myth as a way of world cognition, and fairy tale itself as a religious text are literally eternal.

For real, fairy tale has the object of religion, which is the eternal idea of good and evil; it sets the main question of religion, which is the question of the real good for one person and the whole humankind. The space of fairy tale is organized on the religious pattern: it always presents the ethic model of the world. Though surprisingly, science is hardly interested in this mystery, which proves the narrowness of science, but not a fairy tale. Moreover, considering that the new generation of the $21^{\text {st }}$ century children have a brightly visual perception and clip consciousness, it would be reasonable to suggest that in the nearest future, the fairy-tale-clip type of religion will dominate.

It is perhaps not that bad, if we consider the opinion of Charles de Lint: "People who've never read fairy tales $\langle\ldots>$ have a harder time coping in life than the people who have. They don't have access to all the lessons that can be learned from the journeys through the dark woods and the kindness of strangers treated decently, the knowledge that can be gained from the company and example of Donkeyskins and cats wearing boots and steadfast tin soldiers. I'm not talking about in-your-face lessons, but more subtle ones. The kind that seep up from your subconscious and give you moral and humane structures for your life. That teach you how to prevail, and trust. And maybe even love" (Solomonova, 2015: 74).

\footnotetext{
Derived from the "cherny" meaning "black" in Russian.
}

\section{References}

Arnoldi, E.M. (1968). Zhizn' i skazki Uolta Disneia [Life and Fairy Tales of Walt Disney]. Leningrad: Iskusstvo. $212 \mathrm{p}$.

Asenin, S. (1995). Uolt Disney. Tayny risovannogo kinomira [Secrets of the Animated World]. Moscow: Iskusstvo. 318 p.

Bakhtin, M.M. (1975). Voprosy literatury i estetiki [Questions of Literature and Aesthetics]. Moscow: Hudozhestvennaja literatura. 504 p.

Blok, A.A. (1962). Pamiati Vrubelia [In Memory of Vrubel], In: Blok, A.A. Sobr. soch. v 8-mi tomakh [Collected Works in 8 Volumes]. Moscow-Leningrad: State publishing house for fiction literature.

Botnikova, A.B. (2005). Nemetskiy romantizm - dialog khudozhestvennykh form. Vysshaia faza $i$ zavershenie zhanra (Skazki E.T.A. Gofmana) [German Romanticism as a Dialogue of Art Forms. The 
Climax and End of the Genre (Fairy Tales by E.T.W. Hoffman)]. Available at: http://19v-euro-lit.niv. $\mathrm{ru} / 19 \mathrm{v}$-euro-lit/botnikova-nemeckij-romantizm/vysshaya-faza-i-zavershenie-zhanra.htm

Colbert, D. (2003). Volshebnye miry "Vlastelina Kolets" [The Magical Worlds of the Lords of the Rings"']. Moscow: Rosmen. 192 p.

Deleuze, G. (2000). Kriticheskaia filosofiia Kanta: uchenie o sposobnostiakh. Bergsonizm. Spinoza [Kant's Critical Philosophy: Doctrine of the Faculties. Bergsonism. Spinoza]: translated from French. Moscow. 351 p.

Gruzdeva, E.N., Kolmykova, V.V. (2011). "Vlastelin kolets" kak mif postindustrial'nogo, setevogo i informatsionnogo obschestva ["The Lords of the Rings" as a Myth of Post-Industrial, Network and Information Society]. In: Voprosy filosofii [Philosophy Issues], 8, 75-84.

Ivanova, E. (1999). Mifologiia dobra i zla [Mythology of Good and Evil]. Yekaterinburg: Ural University Publishing House. 88 p.

Korol'kova, Ya. (2010). O sootnoshenii literaturnoy skazki i fentezi [On the Correlation Between Literary Fairy Tale and Fantasy], In: Vest. Tomskogo gos. ped. un-ta [Tomsk State Pedagogical University Newsletter], 8, 142-144.

Kuznetsova, A.V. (2014). Muzykal'naia mifologema "Volshebnaia fleyta" V.A. Motsarta kak predtecha sinteza semioticheskikh sistem mifa i muzyki v romantizme [Musical Mythologeme of the "Magic Flute" by W.A. Mozart as a Precursor of the Synthesis of Myth and Music Semiotic Systems in Romanticism], In: Nauchnye vedomosti [Science Newsletter], 9, 153-156.

Lem, S. (1970). Fantastika i futurologiia [Fiction and Futurology]. Available at: http://thelib.ru/ books/lem_stanislav/fantastika_i_futurologiya_kniga_1.html

Literaturnyy entsiklopedicheskiy slovar' [Encyclopaedical Dictionary of Literature] (1987). Moscow: Sovetskaia entsiklopediia. 751 p.

Loyko, O.T. (2002). Fenomen social'noj pamiati [Social Memory Phenomenon]. Tomsk, Tomsk University Publishing House. 256 p.

Perkhin, V. (2011). Russkaia Zolushka elizavetinskikh vremion [Russian Cinderella of the Elisabeth Age], in: Moscow, 12, 166-170.

Propp. V.Ya. (1986). Istoricheskie korni volshebnoy skazki [The Historical Roots of the Wonder Tale]. Leningrad: Leningrad University Publishing House.

Rou, A.A. (1973). Skazka na ekrane. "S kem i kak ia sozdaval skazki" [Fairy Tale on Screen. "How and With Whom I Created My Fairy Tales"]. Chekhov.

Schwartz, E.L. (1992). Obyknovennoe chudo: p'esy [The Ordinary Miracle: Plays]. Leningrad: Lenizdat. 412 p.

Solomonova, M.V. (2015). Granitsy zhanrov fentezi i volshebnoy skazki v sovremennoy angloiazychnoy literature [Borders of Fantasy and Fairy Story Genres in Modern English Literature] In: Vestnik Leningradskogo gosudarstvennogo un-ta im. A.S. Pushkina [A.S. Pushkin Leningrad State University Newsletter], 4(1), 74-81.

Tolkien, J.R.R. (2010). O volshebkykh skazkakh [On Fairy Stories], In: Tolkien, J.R.R. Skazki volshebnoy strany [The Magic Land Stories]. Moscow: Ast: AstMoskva, 315-414.

Zinkevich-Evstigneeva, T.D. (2016). Praktikum po skazkoterapii [Fairy Tale Therapy Practicum]. Saint Petersburg, Moscow: Rech'. 320 p. 


\section{Великие сказочники мира \\ о путешествии души во Вселенной}

\section{О.А. Карлова}

Сибирский федеральный университет Россия, 660041, Красноярск, пр. Свободныій, 79

Статья посвящена актуальному содержанию сказки как культурного гаджета человечества. Уточняя функции сказки как носителя культурной памяти и интуитивного нормативного знания человечества, автор поднимает проблемы отражения в сказках народных идеалов в историко-культурной ретроспективе, включая эпоху постиндустриального сетевого информационного общества, обозначает рамки участия сказки в проектировании жизни, а также формулирует гипотезу о природе безразличия сказки к соблюдению границы между жизнью и смертью.

Ключевые слова: миф, сказка, сказочный архетип, хронотоп сказки, народная и литературная сказка, фэнтези, сказкография, сказкотерапия.

Научная специальность: 09.00.00 - философские науки. 